\title{
Correction to: Isolation, characterization and antiproliferative evaluation of constituents from stem extracts of Alafia barteri Oliv. Hook. F.
}

\author{
Abdulmumeen A. Hamid ${ }^{1}$ - Olapeju O. Aiyelaagbe ${ }^{2}$ Fatima Kaneez $^{3}$. \\ Suaib Luqman ${ }^{3} \cdot$ Arvind S. Negi $^{3}$
}

Published online: 26 December 2017

(C) Springer Science+Business Media, LLC, part of Springer Nature 2017

Correction to: Med Chem Res (2017) 26:3407-3416 https://doi.org/10.1007/s00044-017-2033-4

The original version of this article unfortunately contained a mistake. The first sentence under the sub-heading "Cell culture and MTT assay for cell viability" is incorrect. The corrected sentence is given below, "Three human cancer cell lines namely K562 (Leukemia), WRL68 (hepatic) and MCF-7 (breast) obtained from National Centre for Cell Science (NCCS), Pune, India were cultured and maintained at CSIR-CIMAP, Lucknow. The cell lines were cultured in DMEM/Ham's F-12 medium containing $10 \%$ heatinactivated FBS, $5 \mathrm{mg} / \mathrm{mL}$ of penicillin, $10 \mathrm{mg} / \mathrm{mL}$ of neomycin, and $5 \mathrm{mg} / \mathrm{mL}$ streptomycin."

The original article can be found online at https://doi.org/10.1007/ s00044-017-2033-4.

Abdulmumeen A. Hamid hamidmemo@gmail.com hamd.aa@unilorin.edu.ng

1 Department of Chemistry, University of Ilorin, Ilorin, Kwara State, Nigeria

2 Department of Chemistry, University of Ibadan, Ibadan, Oyo State, Nigeria

3 Central Institute of Medicinal and Aromatic Plants (CIMAP), Lucknow, India 